\title{
Tanulmányok
}

\section{KÉMIA A FÖLDRAJZTANÍTÁSBAN}

CHEMISTRY IN GEOGRAPHY TEACHING

\section{VARGA ANDREA}

Szegedi Tudományegyetem Földrajzi és Földtudományi Intézet Ásványtani, Geokémiai és Kőzettani Tanszék raucsikvarga@geo.u-szeged.hu

\begin{abstract}
The periodic table of chemical elements is a common language for science, capturing the essence not only of chemistry, but also of earth sciences, including geography and geochemistry. This study provides chemical examples for project tasks in geography teaching.
\end{abstract}

Keywords: periodic table, geographical elements, economic geology, rare earth elements, diffusion, adsorption

\section{Bevezetés}

Az Egyesült Nemzetek Szervezete a 2019-es évet a Periódusos Rendszer Nemzetközi Évének nyilvánította, hiszen ekkor ünnepeljük a Mengyelejev-féle periódusos rendszer közzétételének (1869) 150 éves évfordulóját. Dmitrij Ivanovics Mengyelejev (1834-1906) orosz kémikus az ismert elemeket még atomtömeg alapján rendezte; a napjainkban elterjedt, úgynevezett hosszú periódusos rendszer azonban már az elemek elektronszerkezetének törvényszerűségeit tükrözi (AtKins, P. W. 1995, GreEnwood, N. N. Earnshaw, A. 2004, Whitten, K. W. et al. 2014, Varga A. 2019).

A periódusos rendszert nemcsak kémiai szempontból fontos ismernünk, hanem számos földtudományi kérdéskör (pl. ásványok összetétele, mállás, érctelepek képződése, természetes vizek kémiai összetételét meghatározó folyamatok, megújuló energiaforrások hasznosítása) magyarázatakor is segítségül hívhatjuk. Eredményesen használható az elemek és a belőlük képződő vegyületek kémiai tulajdonságainak megértésekor, így a földtudományok kémiai alapjait sem érthetjük meg előzetes tárgyalása nélkül (White, W. M. 2002, Gill, R. 2015). Ennek megfelelően kapott helyet a Szegedi Tudományegyetem földtudományi képzéseiben (földrajz alapszak, földtudományi alapszak, földrajztanár szak) az általános és szervetlen kémiai háttérismeret bemutatásakor (VARGA A. 2019). A komplex természettudományos szemlélet kialakításához a földrajztanításba is becsempészhető a kémia, jelen tanulmány ehhez szeretne néhány egyszerü ötletet adni. 


\section{Elemi földrajz - földrajzi vonatkozású elemnevek}

A természetben előforduló és a mesterségesen elöállított elemek az atommagjukban található protonok száma, azaz a rendszám (jele: Z) szerint sorba rendezhetők. Az elem tehát azonos rendszámú atomok halmaza. Az elemeket a latin vagy görög nevükből származó rövidítéssel, a vegyjellel jelöljük. A középkorban még csak kilenc elemet ismertek (arany, ezüst, réz, ón, ólom, higany, vas, kén és szén), amelyeket többnyire valamelyik jellemző tulajdonságukról neveztek el; pl. arany, Au - aurum: sárga; ezüst, $\mathrm{Ag}$ - argentum: fénylő; réz, $\mathrm{Cu}$ - cuprum: ciprusi; ólom, $\mathrm{Pb}$ - plumbum: nehéz; higany, $\mathrm{Hg}$ - hydrargyrum: ezüstös víz (At kins, P. W. 1995, Whitten, K. W. et al. 2014). Ma már 118 az ismert elemek száma, és majdnem pontosan egynegyedüknek neve földrajzi vonatkozású (1. ábra, 1. táblázat). Mengyelejev munkásságának emléket állítva a 101-es rendszámú mesterségesen előállított elemet (Md: mendelévium) róla nevezték el (Whiтe, W. M. 2013).
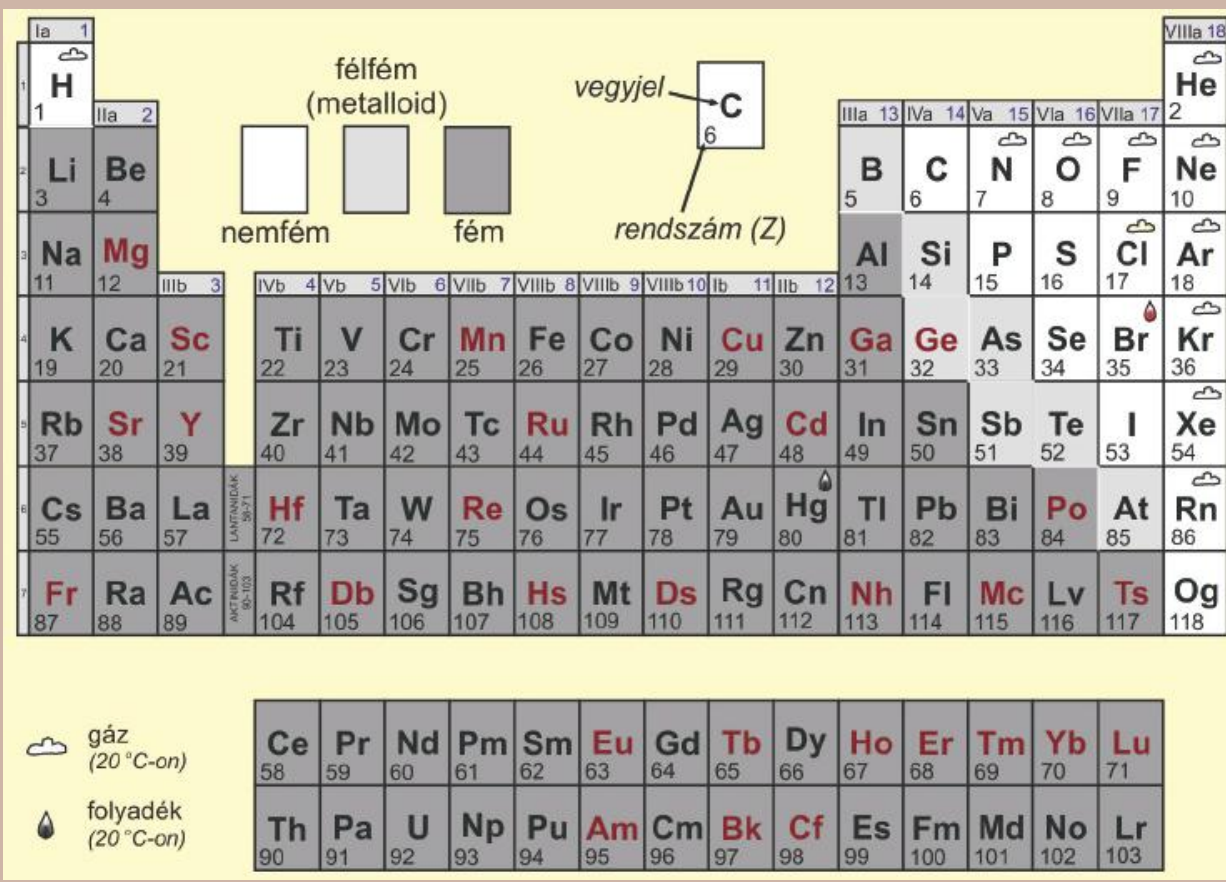

1. ábra. Elemi földrajz a periódusos rendszerben (ATKINS, P. W. 1995, GREENWOOD, N. N. - EARNSHAw, A. 2004, WhitTEN, K. W. et al. 2014 és VARGA A. 2019 nyomán). A földrajzi vonatkozású elemek vegyjele bordó szinü. Érdemes megfigyelni, hogy egy kivétellel (Ge: germánium, félfém) valamennyi a fémek közé tartozik. 


\begin{tabular}{|c|c|c|c|}
\hline Z & Vegyjel & Név & Név eredete (földrajzi megnevezés) \\
\hline 12 & $\mathrm{Mg}$ & magnézium & $\begin{array}{l}\text { Az ókori görögországi (thesszáliai) Magnesiában lévő fehér földön (latinul } \\
\text { magnes carneus) található ércekből állítható elő; magnesia alba ( } \mathrm{MgCO}_{3} \text {, } \\
\text { magnézium-karbonát) }\end{array}$ \\
\hline 21 & Sc & szkandium & Skandinávia, latinul Scandia \\
\hline 25 & $\mathrm{Mn}$ & mangán & $\begin{array}{l}\text { Az ókori görögországi (thesszáliai) Magnesiában található ércekből állítható } \\
\text { elő; magnesia nigri ( } \mathrm{MnO}_{2} \text {, mangán-dioxid) }\end{array}$ \\
\hline 29 & $\mathrm{Cu}$ & réz & $\begin{array}{l}\text { Ciprus szigetén gazdag lelőhelye volt, latin nevét (cuprum) a sziget ókori } \\
\text { nevéről (Kupros) kapta }\end{array}$ \\
\hline 31 & $\mathrm{Ga}$ & gallium & $\begin{array}{l}\text { 1. Franciaország, latinul Gallia } \\
\text { 2. Felfedezójének neve (rejtetten magáról nevezte el): François Lecoq de } \\
\text { Boisbaudran (a francia kakas, le coq, latinul Gallus gallus) }\end{array}$ \\
\hline 32 & Ge & germánium & Németország, latinul Germania \\
\hline 38 & $\mathrm{Sr}$ & stroncium & Strontian község, Skócia \\
\hline 39 & Y & ittrium & Ytterby, svéd város Stockholm közelében \\
\hline 44 & $\mathrm{Ru}$ & ruténium & Ruthenia (Oroszország középkori latin neve után) \\
\hline 48 & $\mathrm{Cd}$ & kadmium & Kadmeiai föld, ókori Görögország (Théba) \\
\hline 63 & $\mathrm{Eu}$ & európium & Európa (kontinens) \\
\hline 65 & $\mathrm{~Tb}$ & terbium & Ytterby svéd város Stockholm közelében \\
\hline 67 & Ho & holmium & Stockholm, latinul Holmia \\
\hline 68 & Er & erbium & Ytterby, svéd város Stockholm közelében \\
\hline 69 & $\operatorname{Tm}$ & túlium & Thulium, Skandinávia régi neve \\
\hline 70 & $\mathrm{Yb}$ & itterbium & Ytterby, svéd város Stockholm közelében \\
\hline 71 & Lu & lutécium & Párizs, latinul Lutetia \\
\hline 72 & $\mathrm{Hf}$ & hafnium & Koppenhága, latinul Hafnia \\
\hline 75 & $\operatorname{Re}$ & rénium & Rajna folyó, latinul Rhenus \\
\hline 84 & Po & polónium & Lengyelország, lengyelül Polska \\
\hline 87 & $\mathrm{Fr}$ & francium & Franciaország, franciául France \\
\hline 95 & Am & amerícium & Amerika (kontinens) \\
\hline 97 & $\mathrm{Bk}$ & berkélium & $\begin{array}{l}\text { Berkeley, város, USA (a Berkeley-ben lévő University of California kutatóinak } \\
\text { állít emléket) }\end{array}$ \\
\hline 98 & Cf & kalifornium & $\begin{array}{l}\text { Kalifornia, állam, USA (a Berkeley-ben lévő University of California kutatóinak } \\
\text { állít emléket) }\end{array}$ \\
\hline 105 & $\mathrm{Db}$ & dubnium & $\begin{array}{l}\text { Dubna, oroszországi város (az itt található atommagkutató intézet kutatói- } \\
\text { nak tiszteletére) }\end{array}$ \\
\hline 108 & Hs & hasszium & Hessen, németországi tartomány, latinul Hassia \\
\hline 110 & Ds & darmstadtium & Darmstadt, német város \\
\hline 113 & $\mathrm{Nh}$ & nihónium & Japán, japánul Nihon \\
\hline 115 & Mc & moszkóvium & $\begin{array}{l}\text { Moszkvai terület, Oroszország (megjegyzés: nem Moszkva, a város a név- } \\
\text { adó, hanem a régió) }\end{array}$ \\
\hline 117 & Ts & tennesszium & Tennessee, állam, USA \\
\hline
\end{tabular}

\section{1. táblázat. Földrajzi vonatkozású elemnevek (VARGA A. 2019 nyomán)}


Európa földrajzának tanításakor - házi vagy szorgalmi feladatként, csoportmunkában szakköri vagy fakultációs foglalkozáson, természettudományos témahéthez kapcsolódva - érdemes kitérni a „periódusos birodalom” földrajzára, hiszen az 1. táblázatban szereplő 30 elemnévből Európa szolgáltatta a legtöbbet. Maga a kontinens is névadó (európium), de egyes országai (pl. Németország - germánium), tartományai (pl. moszkvai régió moszkóvium), városai (pl. Ytterby - ittrium), sőt egy folyója (Rajna - rénium) szintén megtalálható a nevek sorában. A periódusos rendszer és egy térkép segítségével a földrajzi nevek és a róluk elnevezett elemek könnyen összepárosíthatók (2. ábra).

\section{Technológiai kihívások a 21. században: a ritkaföldfémek}

A földrajzi vonatkozású elemnevek eredetét tanulmányozva érdemes kiemelni Ytterby svéd várost, hiszen nevéhez négy elem is köthető (1. táblázat): az átmenetifém ittrium (Y), valamint a ritkaföldfém terbium (Tb), erbium (Er) és itterbium (Yb). Kémiai és geokémiai értelemben ezek hasonló tulajdonságú, rokon elemek. Az Y és

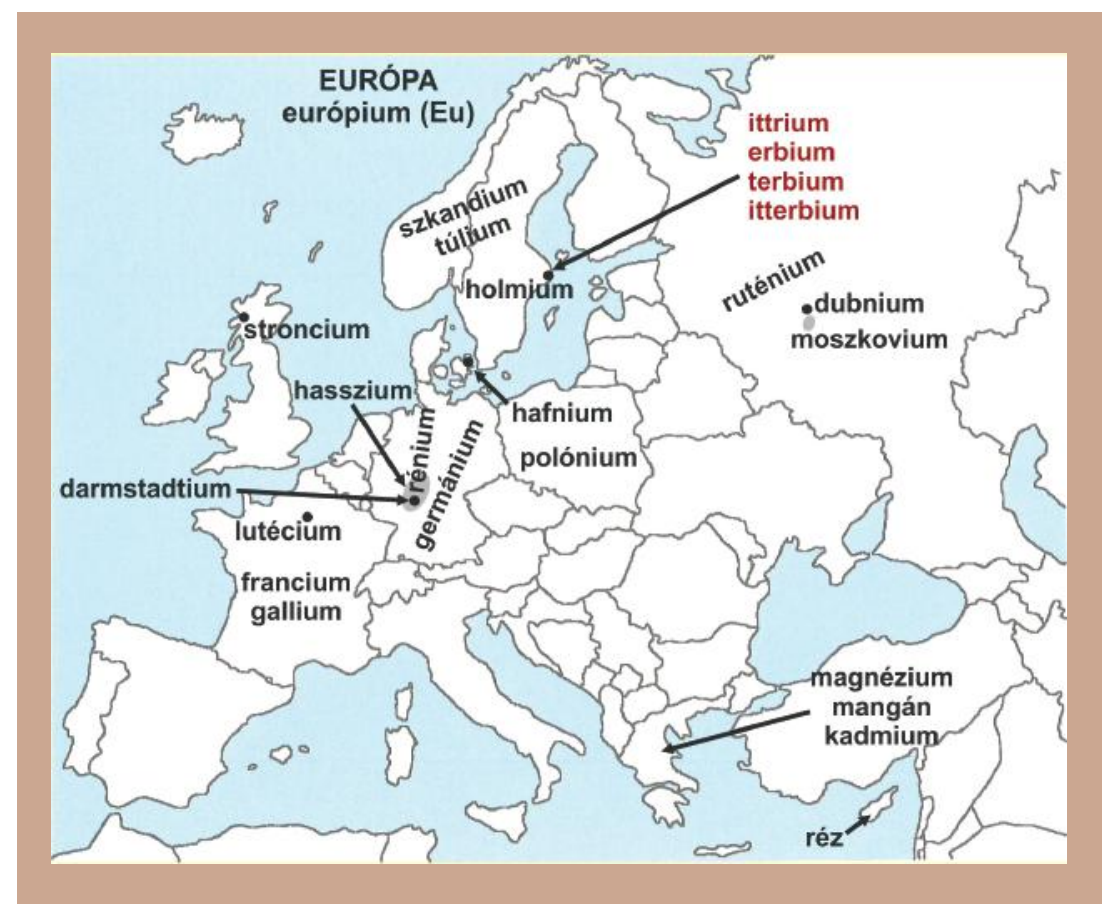

2. ábra. Európához kapcsolódó földrajzi vonatkozású elemnevek (WHITTEN, K. W. et al. 2014, VARGA A. 2019). A névadó városok helyét fekete pont, a régiókat szürke alakzat jelöli. 
a szkandium (Sc) mellett a lantánt (La) követö 14 elem - ezüstös színü vagy halványsárga, viszonylag puha fémek -, a lantanidák (Ce: cérium, Pr: prazeodímium, Nd: neodímium, Pm: prométium, Sm: szamárium, Eu: európium, Gd: gadolínium, Tb: terbium, Dy: diszprózium, Ho: holmium, Er: erbium, Tm: túlium, Yb: itterbium, Lu: lutécium) együtt alkotják a ritkaföldfémek tágabb csoportját (GreEnWOod, N. N. Earnshaw, A. 2004, White, W. M. 2013, Whitten, K. W. et al. 2014, Varga A. 2019). Ezek az elemek sokáig a kémiában is háttérbe szorultak, a 21. század technológiai kihívásai, a megújuló energiára épülő energiaszektor fokozatos térhódítása azonban egyértelmüvé tette fontosságukat (Doвоsı G. - TöRöK K. 2012; BRAUn T. 2018; Perry, E. P. - Gysi, A. P. 2018).

A ritkaföldfémek általában nyomnyi mennyiségben (összesen néhány 10-100 g/t) fordulnak elő a földkéregben - részben erre utal az összefoglaló nevük -, valójában azonban nem ritka elemek, csak nem alkotnak olyan önálló ásványokat, amelyek a gyakori kőzetekben feldúsulnának (HARANGI Sz. et al. 2003, 2013). Átlagos gyakoriságukat jól jelzi, hogy a ritkaföldfémek gyakoribbak a földkéregben, mint az ezüst, közülük a lantán és a cérium gyakorisága még a rézét is meghaladja. Ez alól egyedül a prométium a kivétel, mert ez nem fordul elő a természetben. Számottevő mennyiségben az urán maghasadása során képződik, ezért a nukleáris reaktorok kiégett fütőanyagában található meg (Dовоsı G. - TöRöк K. 2012, BRAUn T. 2018).

\section{A ritkaföldfémek gazdasági jelentősége}

A ritkaföldfémek felhasználása sokrétü, több iparágazatban - pl. energetika, fémipar, mikroelektronika, hadiipar, akkumulátor- és katalizátorgyártás, üveggyártás és kerámiaipar - kulcsszerepet tölt be ez az elemcsoport, mint olyan nyersanyag, ami jelenlegi ismereteink szerint mással nem helyettesíthető. A plazma- vagy LCD-kijelzők (pl. monitor, TV-képernyö) világító képpontjaihoz ritkaföldfém-vegyületekre van szükség (pl. vörös képpont: európium). Az energiatakarékos lámpákban, LED-ekben szintén a ritkaföldfémek fluoreszcens tulajdonságát hasznosítják. További felhasználási terület az optikai kábelek és a lézerek gyártása. A legerősebb permanens mágnesek eloállításához is ritkaföldfém-ötvözetekre van szükség. Segítségükkel valósult meg számos elektronikai alkatrész (pl. merevlemezek, DVD-lejátszók, hangfalak) miniatürizálása. Neodímium-mágneseket legnagyobb mennyiségben a szélturbinák generátoraiban használnak fel (Doвоsı G. - Töröк K. 2012, BRAUn T. 2018). 
Gazdasági szempontból jelentős, azaz ércnek tekinthető ritkaföldfémtelepek speciális magmás előfordulásokhoz kapcsolódnak (pl. Bayan Obo és Maoniuping, Kína; Strange Lake, Kanada; Mountain Pass és Bear Lodge, USA; Olympic Dam, Ausztrália). Az ismert készletek jelentős része Észak-Amerikában, Afrikában (Namíbia, Malawi, Dél-Afrika), Ausztráliában és Délkelet-Ázsiában van. A Bayan Obo-érctelep a Föld legnagyobb ismert ritkaföldfém-telepe, ezért nem meglepő, hogy a világtermelés közel 97\%-a Kínához kötődik (Doвosi G. - Töröк K. 2012, Perry, E. P. - Gysi, A. P. 2018). A másodlagos ritkaföldfémtelepek a mállás, illetve az azt követő üledékfelhalmozódás eredményeként jönnek létre (pl. torlatos dúsulás). Az úgynevezett ionadszorpciós telepek (Kína) olyan másodlagos felhalmozódások, amelyek magmás kőzetek (elsősorban gránit) mállása során képződnek. Ennek során a gránit elsődleges ásványai (pl. földpátok, csillámok, cirkon, monacit, apatit) átalakulnak, részben feloldódnak, amit a ritkaföldfémek felszabadulása kísér. A mállástermékben található agyagásványok a rétegszilikátok egyik csoportja - képesek a felületükön megkötni, azaz adszorbeálni a ritkaföldfémeket (Dовоsı G. - Тӧвӧк K. 2012).

Magyarországon nem ismert természetes ritkaföldfém-dúsulás, azonban a timföldgyártás melléktermékeként keletkezö vörösiszapban feldúsulnak ezek az elemek, az ionadszorpciós telepekhez hasonlóan elsősorban adszorbeált formában, és gyenge savak segítségével kioldhatók. Az előzetes vizsgálati eredmények szerint a rétegszilikátokon megkötődött ritkaföldfémek mintegy 60\%-a mobilizálható a vörösiszapból (Dobosi G. - Török K. 2012), ezért napjainkban kiemelt szerepet kapnak a gazdaságos kinyerésüket célzó kutatások (pl. VíGH Cs. et al. 2016, M. То́тн T. et al. 2018).

\section{Ritkaföldfémek a földtudományokban: geokémiai jelentöség}

A ritkaföldfémek földtudományi jelentőségét már a 20. század végén felismerte a modern geokémia (Harangi Sz. et al. 2003). Ezek az elemek általában nem alkotnak önálló ásványt, hanem helyettesítő nyomelemként lépnek be gyakori és kőzetalkotó ásványok (pl. gránát, földpátok) kristályrácsába, ahol a hasonló ionméretű kalciumot vagy nátriumot helyettesítik. A ritkaföldfémek töltése általában +3 , az azonos töltés és a hasonló ionsugár miatt a természetes rendszerekben mindig együtt fordulnak elő. A viszonylag nagy töltés miatt a ritkaföldfémek a vizes oldatokban kevéssé oldódnak, gyakran szilárd fázisokon (pl. a talajt alkotó komponensek) megkötődnek, ezért geokémiai szempontból immobilisnak tekinthetők. A ritkaföldfémek földtörténeti léptékben is felhasználhatók 
az egykori geológiai folyamatok feltárására, képződmények közötti rokonság bizonyítására (geokémiai korreláció). Eredményesen alkalmazhatók a magmás folyamatok (pl. olvadékképződés) nyomon követésére, sőt a törmelékes üledékes rendszerekben (pl. agyagkő, homokkő) a szemcsék eredetének meghatározására is (HARANGI Sz. et al. 2003, 2013, 2015, Dobosi G. - Töröк K. 2012, White, W. M. 2013, MÉszÁros E. et al. 2019, VARgA A. 2019). A genetikai információk feltárásához leggyakrabban speciális viszonyítási alap segítségével szerkesztett geokémiai elemeloszlási diagramokat használnak fel, erre mutat példát a 3. ábra.

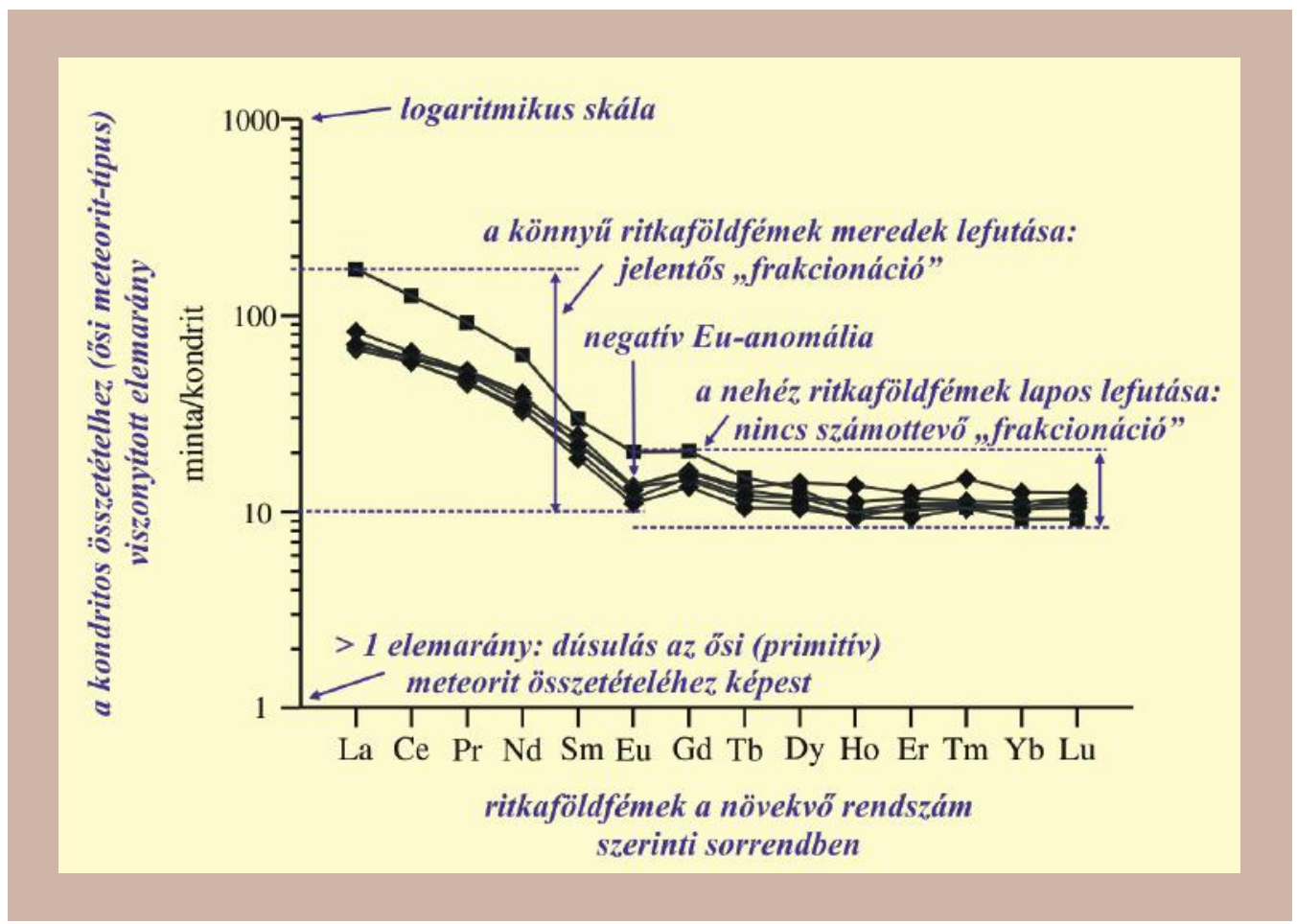

3. ábra. Speciális ritkaföldfém-eloszlási diagram mélyfúrásokból ismert dél-dunántúli szilur időszaki ( 430-440 millió éves) agyagpala-rétegsor példáján (MÉszÁros E. et al. 2019). A kondritos összetétel olyan ösi meteorit összetételét jelenti, ami az illó komponensek (pl. gázok) kivételével a Naprendszer „ösanyagának” tekinthető. A kondritos összetétel a még belső szférák (mag, köpeny, kéreg) nélküli közetbolygók teljes kémiai összetételének felel meg. A geokémiai gyakorlatban ehhez viszonyítják a minták ritkaföldfémtartalmát, ami a diagramokon látható görbék lefutásán keresztül (pl. egyes csoportok eltérö mértékü dúsulása, azaz frakcionációja; egy-egy elem kiugró viselkedése, azaz anomáliája) a földfejlödés nagyléptékü folyamatainak feltárását és leírását teszi lehetôvé (HARANGI Sz. et al. 2003, 2013, 2015, 


\section{Oldott ionok mozgása és megkötődése a mállás során - egyszerü kémiai kísérletek földrajzi megközelítésben}

A málláshoz kapcsolódóan a másodlagos ásványok képződése nem csak a ritkaföldfémek telepszerủ dúsulásáért felelős, fontos szerepet tölt be a talajzóna és a természetes vizek kémiai összetételének befolyásolásában is. A víz és a vízzel érintkező szilárd anyag között ugyanis speciális agyagmozgási (diffúzió), továbbá megkötődési folyamatok (pl. adszorpció, ioncsere) játszódhatnak le (HETÉNYi M. 1999, BÁRÁNy S. et al. 2011, VARGA A. 2019). Ezek a folyamatok a köznapi életünkben is jelen vannak, ezért felismerésük a természettudományos világkép kialakításához és az összefüggések elmélyítéséhez nélkülözhetetlen.

Az alábbiakban a fogalmak rövid meghatározását követően olyan egyszerü kísérletek leírása következik, amelyeket a földrajz tanítása során be lehet építeni az ismeretek átadásakor (pl. 9. osztály: a vízburok földrajza - vízszennyezés, felszín alatti vizek, a vizek öntisztulása; a Föld szerkezete és folyamatai - érctelepek keletkezése, a talaj). Az önálló megfigyelésen keresztül ezek a kísérletek gondolkodásra késztetnek. Az ok-okozati összefüggések megfogalmazásával az elsajátított ismeretek maradandóbbak lesznek, ami a földrajzoktatásban is alapvető cél (FARSANG A. 2014). Mind a diffúzió, mind az adszorpció jelensége veszélytelen és könnyen beszerezhető anyagok segítségével egyszerűen szemléltethető. A javasolt vizsgálatok többsége akár otthon is elvégezhető.

\section{A diffúzió}

A diffúzió mint anyagmozgási folyamat a részecskék (pl. atomok, molekulák, ionok) hőmozgás következtében kialakult, önálló mozgását jelenti gázokban (pl. légköri folyamatok; illatanyagok terjedése a mindennapokban), folyadékokban (pl. szennyeződések terjedése felszíni vagy felszín alatti vizekben) és szilárd anyagokban. Ez utóbbi esetben a diffúzió jóval lassabb folyamat, ami többnyire a szilárd anyagot tagoló határfelületek mentén játszódik le (pl. ásványok érintkezési határa egy kőzetben; hasadási síkok vagy ikerhatárok egy ásványon belül; törések, repedések), szerepe azonban megkerülhetetlen a szilárd fázisú átalakulási folyamatokban (pl. metamorf átkristályosodás). A diffúziós anyagáramot nem külső hatás (pl. légáramlat vagy keverés) hozza létre, hanem önként indul be, ha az adott rendszer különböző részein legalább egy összetevő koncentrációjában eltérés van. A diffúzió irányát tekintve a nagyobb koncentrációjú helyekről a kisebb koncentrációjú helyek felé irányul. A mozgás sebessége függ a hőmérséklettől (magasabb 
hőmérsékleten gyorsabb a részecskék hőmozgása), valamint arányos a koncentráció különbségével. Ha elegendően hosszú idő áll rendelkezésre, az anyag részecskéi minden irányba egyforma valószínűséggel mozognak, idegen szóval diffundálnak mindaddig, amíg az összetevők eloszlása homogén nem lesz (BÁRÁny S. et al. 2011, GiLL, R. 2015, VARgA A. 2019).

\section{Vizsgálatok a diffúzió szemléltetésére}

\section{1. vizsgálat}

Anyagszükséglet: átlátszó, színtelen edény (pl. pohár, kancsó, főzőpohár), víz, teafilter. A vizsgálat menete: óvatosan helyezzünk egy teafiltert a pohárba vagy kancsóba töltött víz felszínére úgy, hogy az ne süllyedjen le! Figyeljük meg a változást (4. ábra)!

Időszükséglet: $3-5$ perc.

Rövid értelmezés: a vízzel érintkezve a teafilterben található színanyagok beoldódnak a vízbe, a kialakuló koncentrációkülönbség pedig azonnal beindítja a diffúziós anyagáramlást.

\section{2. vizsgálat}

Anyagszükséglet: átlátszó, színtelen pohár, tömény szörp (cukorszirup), víz.

A vizsgálat menete: öntsünk a pohárba kb. egy ujjnyi tömény szörpöt, majd nagyon óvatosan csorgassunk rá vizet úgy, hogy lehetőleg ne történjen keveredés! Ehhez célszerü a szörpöt tartalmazó poharat kissé megdönteni, és a vizet lassan, vékony sugárban a pohár belső falára csorgatni. Tegyük félre a poharat, majd vizsgáljuk meg a határfelület

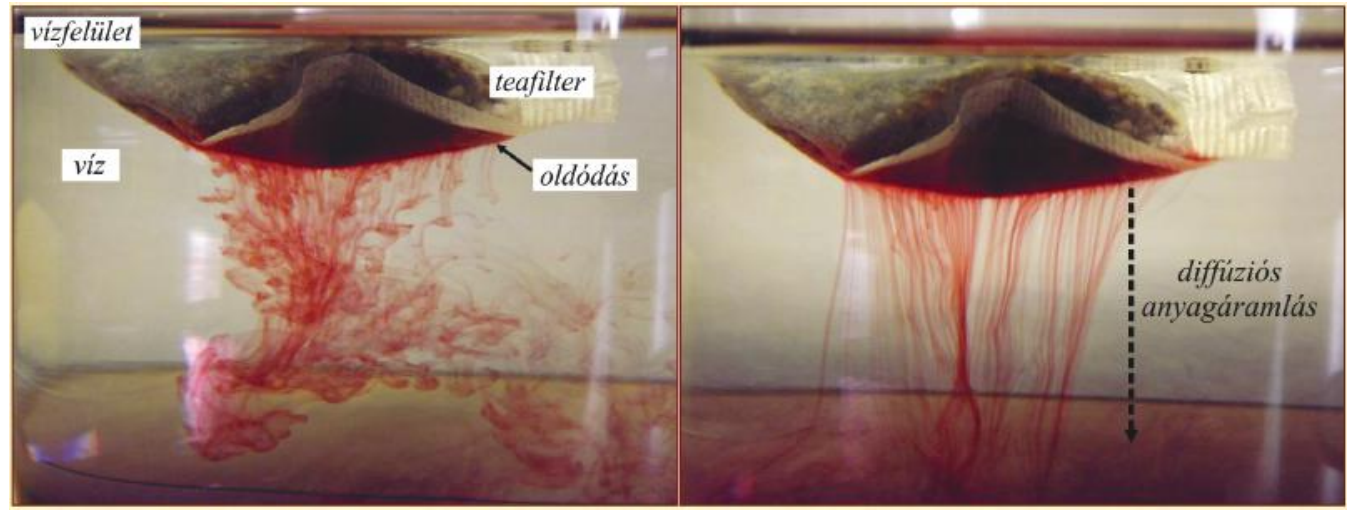

4. ábra. A diffúzió megfigyelése folyadékban: a víz felszinére helyezett teafilterből a kioldódó festékanyag a vizes oldatba diffundál addig, amíg az összetevök eloszlása homogén nem lesz. A nagyobb sürüségü (töményebb) oldatrész felül helyezkedik el, ezért a diffúzió viszonylag gyorsan lejátszódik. 
jellegét 1-2 óra, 5 óra, majd egy nap elteltével (5. ábra)! Időszükséglet: az összeállítás néhány perc, a megfigyelés a várakozás miatt időigényes. Rövid értelmezés: a kiindulási éles határfelület először kiszélesedik, elmosódott lesz (innen származik a „diffúz határ” kifejezés), majd teljesen eltűnik, a rendszer homogenizálódik.

\section{Azadszorpció}

Az adszorpció gáz (gőz), folyadék, illetve finoman eloszlatott, azaz diszpergált szilárd összetevő megkötődése egy szilárd anyag (az úgynevezett adszorbens) felületén. Az adszorpció önként lejátszódó felületi jelenség, ami lehet tisztán fizikai jellegü (fizikai adszorpció vagy fiziszorpció), amikor gyenge másodrendű kötőerők lépnek fel a szilárd felület és a megkötött anyag részecskéi között; illetve kémiai jellegű (kémiai adszorpció vagy kemiszorpció), amikor a felületen kémiai reakció is lejátszódik. Az adszorpció általában megfordítható folyamat, ellentétje a deszorpció, amikor az adszorbens felületéről távozik a megkötött anyag (BÁráNy S. et al. 2011, VARGA A. 2019).

Az adszorpcióhoz szükséges szilárd anyag nagy aktív felülettel rendelkezik, gyakran porózus, lyukacsos szerkezetű. Az iparban ilyen a szilikagél (mesterségesen elő́llított szilícium-dioxid változat) vagy az aktív szén. A talajban, illetve az élővizek lebegő hordalékában hasonló tulajdonsággal rendelkeznek bizonyos alaktalan (amorf) vagy kristályos szervetlen vegyületek (pl. $\mathrm{Fe}^{3+}$ - és $\mathrm{Mn}^{4+}$-oxidok és -hidroxidok, duzzadó agyagásványok, zeolitok). Az adszorpció egyik speciális esete az úgynevezett ioncsere-adszorpció vagy röviden ioncsere, amikor az oldat egyik ionja helyet cserél a szilárd felület valamelyik hasonló töltésű ionjával. Az ioncserének komoly szerepe van a vízlágyításban, a víz

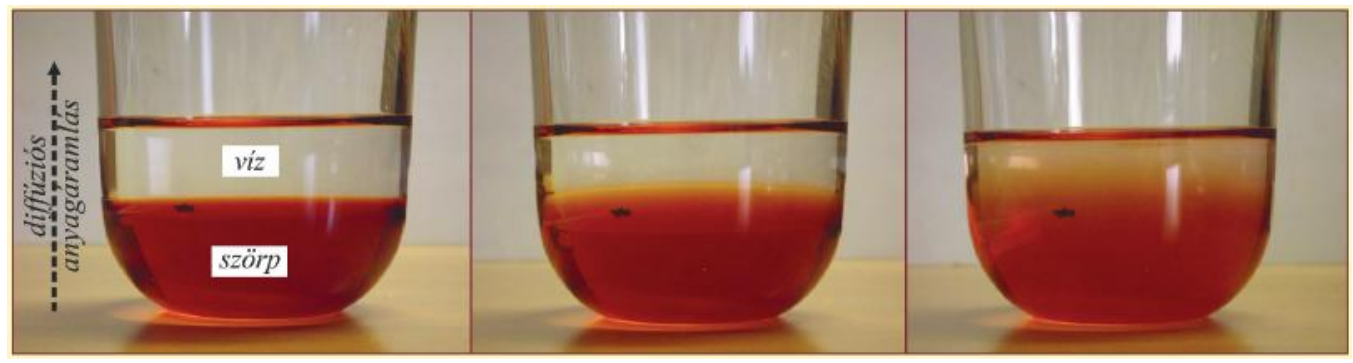

5. ábra. A diffúzió megfigyelése folyadékban: a tömény szörp és a felette elhelyezkedö víz közötti határfelület eleinte éles, majd fokozatosan elmosódóvá (diffúzzá) válik. A nagyobb sürüségü (töményebb) oldatrész alul helyezkedik el, ezért a diffúzió viszonylag lassan játszódik le (középsö kép: fél nap múlva, jobb oldali kép: 2 nap múlva). 
sómentesítésében, továbbá a nehézfém- és radioaktív ionok vizekből és talajból történő eltávolításában. Bizonyos agyagásványok (pl. az ún. szmektitek) kiváló ioncserélő képességűek. A szmektitek kristályrácsának rétegközi terében cserélhető kationok (pl. $\mathrm{Na}^{+}$, $\mathrm{Ca}^{2+}, \mathrm{Mg}^{2+}$ ) és víz helyezkedhet el (Hetényi M. 1999, Bárány S. et al. 2011, VArga A. 2019). A köznapi életben szintén találkozhatunk ilyen anyagokkal: nedvességmegkötő tulajdonságukat a háztartásban és a gyógyászatban is hasznosítják (6. ábra).

\section{Vizsgálatok az adszorpció szemléltetésére}

\section{1. vizsgálat}

Anyagszükséglet: 2 db átlátszó, színtelen pohár, szürőkarika-állvánnyal, tölcsér, szűrőpapír, keverőkanál (vagy üvegbot), porított orvosi széntabletta, színes vizes oldat (pl. ételfestékkel megfestett víz, gyümölcstea).

A vizsgálat menete: öntsünk egy pohárba kb. kétujjnyi színes oldatot, tegyünk bele kb. 2-4 elporított széntablettát, és jól keverjük fel! Egy óra elteltével szűrjük le az aktív szenes oldatot (szuszpenziót)! Figyeljük meg a szürletet, és értelmezzük a lejátszódott jelenséget!

Időszükséglet: az összeállítás néhány perc, a várakozás miatt kissé időigényes kísérlet.

Rövid értelmezés: a szűrést követően kapott oldat halvány színű, vízszerű folyadék lesz. Az aktív szén megkötötte a színes oldatból a színanyagokat, adszorpció ment végbe.

\section{2. vizsgálat}

Anyagszükséglet: 2 db átlátszó, színtelen pohár, keverőkanál (vagy üvegbot), 1 tasak „Smecta”, színes vizes oldat (pl. gyümölcstea).

A vizsgálat menete: az egyik pohárba töltsünk gyümölcsteát, a másikba szórjuk bele a Smecta-tasak tartalmát, ami gyakorlatilag nagy tisztaságú agyagásvány (szmektit)! Az

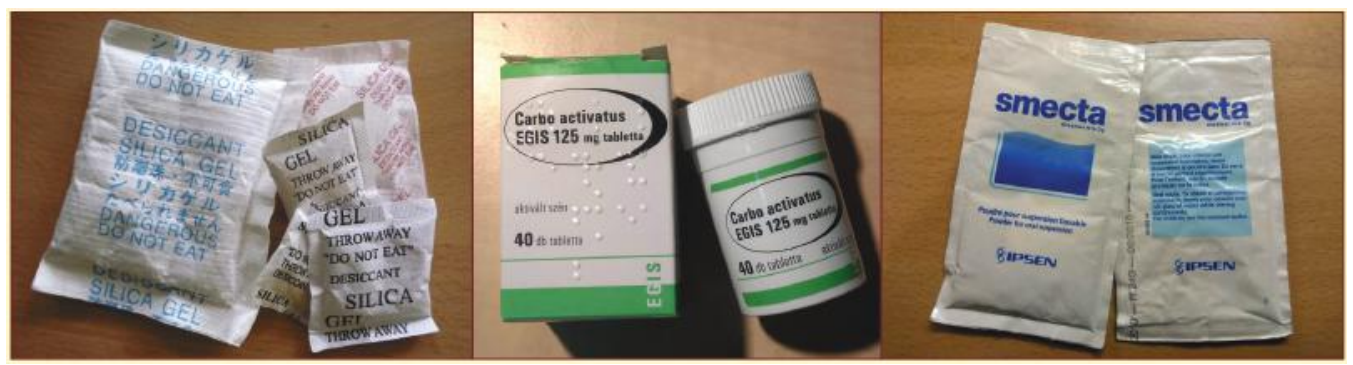

6. ábra. Egyszerü adszorbensek a háztartásban és a gyógyászatban. A szilikagéllel (mesterséges $\mathrm{SiO}_{2}$ változat) töltött tasakok a nem kívánt nedvességet kötik meg (pl. cipők, táskák, elektronikai eszközök mellé helyezve). A széntabletta (aktív szén) és a „smecta” (természetes eredetü, tisztított agyagásvány, szmektit) hasfogó hatású, kiváló vízmegkötő anyagok, ezért hasmenés tüneteinek kezelésére alkalmazhatók. 
agyaghoz keverjünk kb. 5 teáskanál gyümölcsteát, hogy közepes sürüségű szuszpenziót kapjunk! Egy óra elteltével figyeljük meg a szuszpenziót! Hasonlítsuk össze az agyagos szuszpenzió felett elhelyezkedő oldat színét a kiindulási gyümölcstea színével (7. ábra)! Időszükséglet: az összeállítás néhány perc, a várakozás miatt kissé időigényes kísérlet. Rövid értelmezés: a felkevert szuszpenzióból kiülepedik az agyag, ami megköti az oldatból (gyümölcstea) a színanyagokat. Az így keletkezett új oldat ezért szinte vízszerű lesz.

\section{Köszönetnyilvánítás}

A Szegedi Tudományegyetemen a tanulási eredmény alapú tananyagfejlesztést az EFOP-3.4.3-16-201600014 azonosító jelü pályázat AP2 programja támogatta, melynek keretein belül a földrajztanárképzésben is alkalmazott „Híd a kémiához” elektronikus tankönyv készült. A szerző témavezetői és geokémiai korrelációs munkáját a Magyar Tudományos Akadémia Bolyai János Kutatási Ösztöndíja (BO/266/18) és az Emberi Erőforrások Minisztériuma Új Nemzeti Kiválóság Programja (UNKP-18-4-SZTE-16) támogatja.

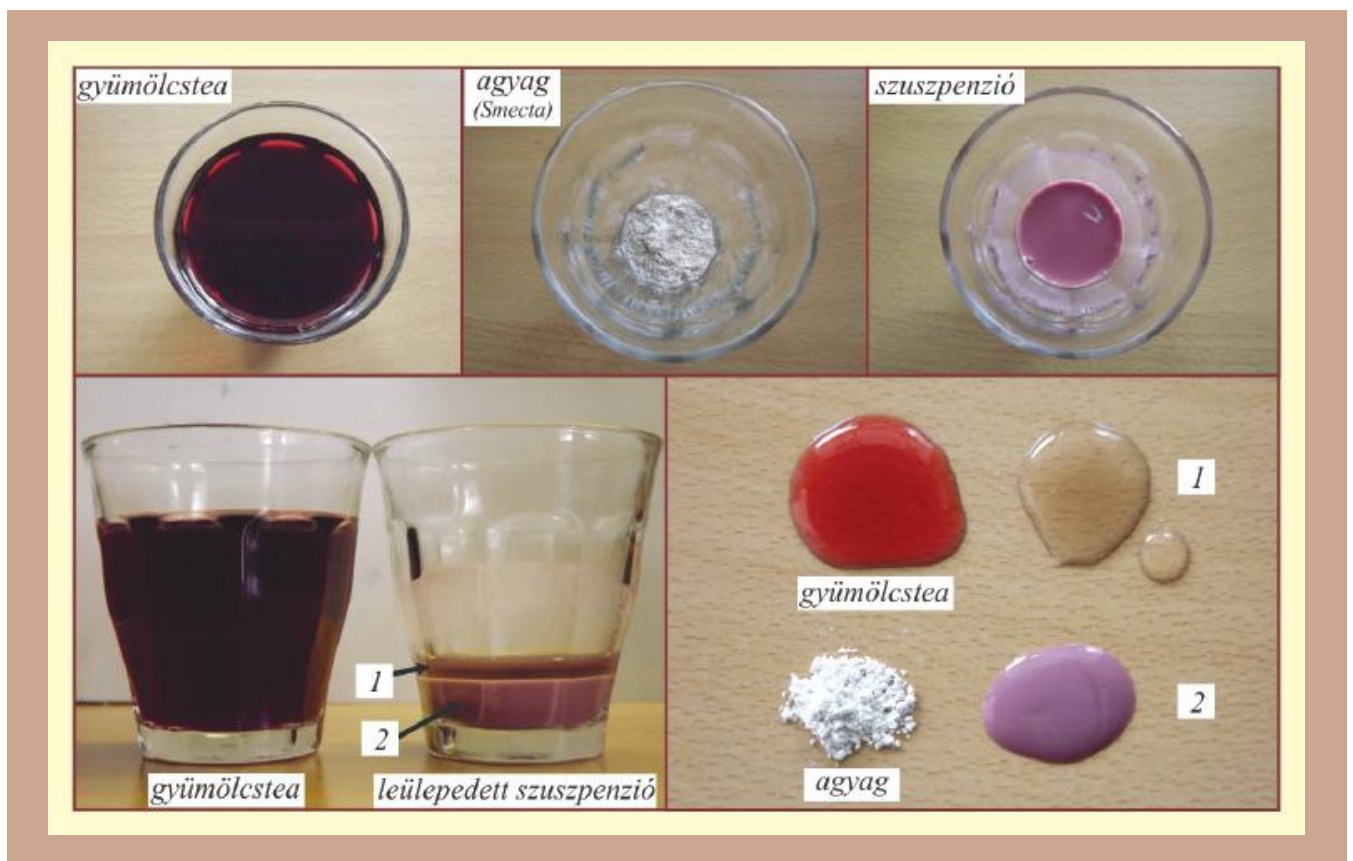

7. ábra. Adszorpció agyagásványok felületén: a gyógyászatban alkalmazott „Smecta” segítségével otthon is megfigyelhetö a felületi megkötődés. Ez a kísérlet segít elképzelni a természetes vizek öntisztulási folyamatát. A Smecta-porból (agyag) és a gyümölcsteából készitett szuszpenzió kb. 1 óra elteltével két részre különül el: a „megtisztult” víz (1) lesz felül, a kiülepedett agyag (2) alul. Összehasonlítva a kiindulási anyagok és a termékek szinét, egyértelmü, hogy az agyag megkötötte a színanyagokat. 


\section{Irodalom}

Atkins, P. W. 1995: A periódusos birodalom. Utazás a kémiai elemek földjére. - Kulturtrade Kiadó, Budapest. 153 p.

BárÁny S. - Baumli P. - Emmer J. - Hutkainé Göndör Zs. - Némethné Sóvágó J. - BÁder A. 2011: Fizikai kémia müszakiaknak. - Elektronikus tankönyv. Nemzeti Tankönyvkiadó, Miskolc. 763 p.

BRAUn T. 2018: Kritikus helyzetben a világ ritkaföldfém-ellátása. Mítosz vagy valóság? - Magyar Kémikusok Lapja 73. 4. pp. 120-126.

Dовоsı G. - Tӧвӧк K. 2012: Ritkaföldfémek geokémikus szemmel. - Magyar Tudomány 173. 5. pp. 541-553.

FARSANG A. 2014: Földrajzi kísérletek és modellek. - GeoLitera, SZTE TTIK Földrajzi és Földtani Tanszékcsoport, Szeged. 140 p.

GILL, R. 2015: Chemical Fundamentals of Geology and Environmental Geoscience. - Wiley-Blackwell, Oxford. $267 \mathrm{p}$.

Greenwood, N. N. - Earnshaw, A. 2004: Az elemek kémiája I-III. - Nemzeti Tankönyvkiadó, Budapest. $1834 \mathrm{p}$.

HARANGi Sz. 2015: Vulkánok. A Kárpát-Pannon térség tűzhányói. - GeoLitera, SZTE TTIK Földrajzi és Földtani Tanszékcsoport, Szeged. 482 p.

Harangi Sz. - Szakmány Gy. - Józsa S. - Lukács R. - SÁgi T. 2013: Magmás kőzetek és folyamatok gyakorlati ismeretek magmás kőzetek vizsgálatához. - ELTE Természettudományi Kar, 566 p. http://www. eltereader.hu/media/2014/05/Magmas_kozetek_READER.pdf.

Harangi Sz. - Lukács R. - Raucsikné Varga A. - Szakmány Gy. - Török K. 2003: Elemek természetes geokémiai eloszlása és elemzési módszereik. - Kézirat. ELTE TTK Kőzettani és Geokémiai Tanszék, Budapest. 150 p.

Hetény I M. 1999: Környezetgeokémia I. A hidroszféra. - JATEPress, Szeged. 156 p.

M. Tóth T. - Schubert F. - Raucsik B. - Bencsik A. 2018: Az almásfüzitői vörösiszap ásványtani és geokémiai jellemzői. - Az asztenoszférától az atmoszféráig. 9. Kőzettani és Geokémiai Vándorgyűlés Absztrakt kötet, Budapest. pp. 111-112.

Mészáros E. - Varga A. - Raucsik B. - Benkó Zs. - Heincz A. - Hauzenberger, C. A. 2019: Provenance and Variscan low-grade regional metamorphism recorded in slates from the basement of the Tisza Mega-unit (SW Hungary). - International Journal of Earth Sciences 108. 5. pp 1571-1593. https://doi. org/10.1007/s00531-019-01720-y

Perry, E. P. - Gysi, A. P. 2018: Rare earth elements in mineral deposits: speciation in hydrothermal fluids and partitioning in calcite. - Geofluids, Article ID 5382480. 19 p. https://doi.org/10.1155/2018/5382480 VARGA A. 2019: Híd a kémiához. A földtudományok általános, szervetlen és fizikai kémiai alapjai. Egyetemi tankönyv. Szegedi Tudományegyetem, Szeged. 305 p. https://doi.org/10.14232/eta.2019.2088 VíGH Cs. - KIss J. - SÁRI K. 2016: Bányászati hulladékkezelő létesítmények kritikus anyagtartalma és 
potenciálbecslési lehetőségei. - Itt az idő! Kőzettani-geokémiai folyamatok és azok geokronológiai vonatkozásai. 7. Kőzettani és Geokémiai Vándorgyűlés Absztrakt kötet, Debrecen. p. 109.

White, W. M. 2013: Geochemistry. - John Wiley \& Sons. 672 p.

Whitten, K. W. - Davis, R. E. - Peck, M. L. - Stanley, G. G. 2014: Chemistry. - Brooks/Cole, Cengage Learning, Belmont. $1190 \mathrm{p}$. 